\title{
Studi Vastu Shastra di Kerajaan Majapahit, Kecamatan Trowulan, Kabupaten Mojokerto
}

\author{
Febe Naulisudena Marbun, Karina Pradinie Tucunan \\ Departemen Perencanaan Wilayah dan Kota, Fakultas Teknik Sipil, Perencanaan, dan Kebumian \\ Institut Teknologi Sepuluh Nopember, Surabaya, 6011 \\ e-mail: kp.tucunan@gmail.com
}

\begin{abstract}
Abstrak-Kecamatan Trowulan yang dikenal dengan 'Kota Majapahit' menyimpan warisan Kerajaan Majapahit sebagai salah satu kerajaan di Indonesia yang menganut kepercayaan Hindu. Kepercayaan yang dianut Kerajaan Majapahit, didukung dengan konsep kosmologi yang terkandung di dalam perencanaan kotanya untuk menjaga keseimbangan alam semesta, memunculkan dugaan adanya adaptasi teori perencanaan tradisional kuno India, yaitu Vastu Shastra, pada perencanaan kota Kerajaan Majapahit.

Penelitian ini ditujukan untuk menyusun Studi Vastu Shastra di Kerajaan Majapahit Kecamatan Trowulan untuk mengenal lebih dalam makna dan identitas berdasarkan warisan peninggalan Kerajaan Majapahit. Langkah yang digunakan untuk mencapai tujuan tersebut yaitu melalui studi literatur dan wawancara mendalam dengan ahli sehingga penemuan yang didapatkan dapat menjawab dugaan pada penelitian dengan melakukan komparasi tata ruang Kerajaan Majapahit di Kecamatan Trowulan dengan konsep Vastu Shastra.

Hasil komparasi tata ruang Kerajaan Majapahit di Kecamatan Trowulan dengan konsep Vastu Shastra menunjukkan adanya adaptasi yang sesuai, meskipun tidak seluruhnya relevan, melainkan hanya di bagian-bagian tertentu yaitu (1) secara Mikro, pada kriteria orientation, living areas, dan floor plans, (2) secara Meso dan Makro, pada kriteria pusat kota, peletakan istana dan peletakan alun-alun, serta (3) pada tipe kota Vastu, yakni Dandaka dan Sarvatobhadra dalam kriteria pusat kota, penataan jalan utama, dan dinding kota, serta Prastara dan Chaturmuka dalam kriteria penataan jalan, penataan bangunan, dan dinding kota.
\end{abstract}

Kata Kunci-Kecamatan Trowulan, Kerajaan Majapahit, Vastu Shastra

\section{PENDAHULUAN}

$\mathrm{H}$ ERITAGE merupakan sesuatu yang dapat diturunkan kepada satu generasi ke generasi selanjutnya, dapat dilestarikan atau diwariskan, serta memiliki nilai historis atau budaya untuk membantu mengingat memori sosial bersama, yang nantinya akan membentuk ide-ide tentang diri kita, baik di masa lalu, masa sekarang, bahkan masa depan. Oleh karena itu, penting mempelajari heritage, dimana sebuah warisan dapat membantu kita menemukan jati diri dan membantu kita dalam menentukan masa depan dari memori masa lalu [1].

Salah satu ilmu yang mempelajari struktur dan sejarah yang berkaitan dengan asal mula dan evolusi untuk mendapatkan gambaran dari pengisi alam semesta berdasarkan ruang dan waktu, peristiwa, dan kemungkinan adanya perkembangan suatu ide di dalamnya adalah kosmologi. Kosmologi menjadi dasar adanya heritage. Pemikiran dalam kosmologi akan menunjukkan adanya pencipta dari alam semesta melalui objek-objek fisik maupun nonfisik tersebut yang akan menceritakan awal dan akhir serta materi yang menciptakan alam semesta [2]. Hal tersebut menyatakan bahwa objek dalam heritage berkaitan dengan adanya kepercayaan suatu masyarakat akan adanya pencipta alam semesta.

Dalam heritage, terdapat produk kebudayaan fisik, yaitu salah satunya adalah produk spasial dan arsitektural yang melahir kan susunan ruang dan bentuk yang erat kaitannya dengan nilai-nilai kehidupan masyarakat pada masa lampau. Tatanan struktur yang membentuk suatu susunan dan ruang yaitu gramatika, sebuah kaidah atau ketentuan yang mengatur terbentuknya struktur ruang serta menjadi dasar dalam penataan ruang. Gramatika menjadi salah satu bentuk heritage yang juga memberikan makna serta membentuk nilai-nilai kehidupan dan identitas [3].

Bentuk produk heritage spasial dan arsitektural telah diterapkan pada masa tradisional kuno India, yaitu Vastu Shastra. Produk tersebut berupa pengetahuan dan teori mengenai perencanaan dan desain, serta sebagai pedoman dalam merancang permukiman manusia dengan tujuan untuk menyeimbangkan antara manusia dengan lingkungannya. Berdasarkan tujuan tersebut, konsep Vastu Shastra dapat menjadi pedoman yang relevan untuk pembangunan berkelanjutan mengingat aktivitas manusia yang mulai membahayakan bumi [4].

Di dalam perencanaanya, Vastu Shastra diatur dalam sebuah diagram simbolik yang disebut Vaastu-PurushaMandala, dimana diagram tersebut akan mempresentasikan 'Vaastu' yang berarti lingkungan, situs, atau bangunan sebagai sebuah konsep untuk mencakup desa, kota, negara, atau bahkan seluruh bumi; 'Purusha' yang merujuk kepada sentuhan manusia, mewakili energi murni, jiwa, kesadaran, kreativitas, dan kecerdasan di alam semesta; serta 'Mandala' yang berarti diagram, diorientasikan sebagai bumi yang dibatasi oleh adanya matahari terbit dan terbenam serta arah mata angin yaitu, timur, barat, utara, dan selatan [5]. Hal tersebut menunjukkan bahwa Vastu Shastra tidak hanya sekadar teori dan pengetahuan tentang perencanaan dan perancangan ruang, namun juga nenunjukkan adanya makna serta nilai yang dapat diadaptasi ke dalam kehidupan modern saat ini.

Kecamatan Trowulan sebagai salah satu daerah di Kabupaten Mojokerto yang dikenal dengan sebutan 'Kota Majapahit' sangat erat kaitannya dengan berbagai warisan peninggalan pada masa Kerajaan Majapahit yang berdiri pada tahun sekitar 1239-1500 Masehi (UNESCO). Kerajaan Majapahit dikenal sebagai kerajaan di Indonesia yang menganut agama Hindu atau dikenal dengan kepercayaan 
Hindu Dharma, yang mengadaptasi dari Hindu Dharma India [6]. Adanya fakta kepercayaan Kerajaan Majapahit yang mengadaptasi kepercayaan India memunculkan adanya dugaan kesamaan pada konsep perancangan kotanya, yaitu dengan konsep Vastu Shastra. Hal ini juga didukung pernyataan yang menyatakan bahwa Kerajaan Majapahit pada masanya merancang kotanya dengan upaya untuk menjaga keseimbangan alam semesta yang akan memberikan keamanan untuk manusia [7], sama dengan tujuan konsep Vastu Shastra yang bertujuan untuk menyeimbangkan manusia dengan lingkungannya.

Tujuan yang dipegang konsep Kerajaan Majapahit dan konsep Vastu Shastra terkait penataan ruangnya mampu mendukung pembangunan berkelanjutan yang menuju ke arah pemberdayaan bumi dan manusia, terutama mengingat Kerajaan Majapahit sebagai bagian sejarah dari Indonesia yang seharusnya mampu menjadi dasar bagi masa depan pembangunan di Indonesia. Dengan demikian, diperlukan penelitian lebih dalam mengenai adanya relevansi konsep Vastu Shastra di dalam penataan ruang Kerajaan Majapahit di Kecamatan Trowulan. Hal ini didukung dengan kurangnya penelitian mengenai konsep Vastu Shastra di Indonesia, terutama dengan kerajaan-kerajaan di Indonesia yang memiliki sejarah kerajaan Hindu

Prinsip-prinsip dasar Vastu Shastra terkait perencanaan sebuah bangunan ada enam, namun di dalam penelitian ini hanya difokuskan pada dua prinsip [4], yaitu:

1) Doktrin Orientasi

Doktrin orientasi ditentukan oleh arah mata angin yang menjadi tanda signifikasi tertentu yang membantu menjelaskan prinsip-prinsip orientasi Vastu Shastra, dimana dalam pengaturan dan perancangan strukturnya dapat diperoleh manfaat dari radiasi matahari yang optimal. Pada pemahaman Vastu, arah matahari terbit dan arah matahari tenggelam sebagai sumber kiblat. Matahari pagi dianggap bermanfaat dan memurnikan, sehingga arah timur dianggap arah yang paling baik dan berharga.

2) Perencanaan Lokasi

Perencanaan lokasi pada Vastu Shastra diatur dalam Vastu-Purusha-Mandala yang dianggap sebagai model semesta dalam membenrikan dasar untuk mendesain arsitektur, yaitu Adanya bangunan (vastu) yang berada dalam keteraturan yang sempurna, maka dapat disimpulkan bahwa terdapat kesadaran manusia di dalamnya. Kemudian, terdapat Purusha yang mewakili energi murni, jiwa, atau kesadaran, semacam kecerdasan, dan kreativitas di alam semesta. Sedangkan, Mandala berarti diagram, yang berkaitan dengan orientasi bahwa bumi dibatasi oleh terbit dan terbenamnya matahari, timur dan barat, serta utara dan selatan.

Prinsip perencanaan lokasi kemudian terbagi menjadi kriteriakriteria [5] yakni:

\footnotetext{
-Orientation (dalam konsep Vastu-Purusha-Mandala, orientasi bangunan ke kondisi cardinal (utama) sebagai sebuah aturan sehubungan dengan jalur matahari);

-Living Areas (area untuk tamu (ruang duduk) di dalam konsep Vastu-Purusha-Mandala akan menghadap ke utara dan timur dengan struktur yang lebih ringan dan terbuka);
}

-Floor Plans (secara umum, perencanaannya adalah berbentuk persegi dengan ruang terbuka berada di tengah dan keempat sisinya akan dibangun rumah sehingga akan membentuk urutan preferensi menghadap ke rumah adalah timur, utara, barat, dan selatan);

-Thermal Mass (daerah sudut barat daya memiliki bangunan dengan bahan yang berat dan struktur yang tinggi untuk mengurangi panas matahari);

-Water Harvesting (dataran memiliki gradien yang miring ke utara dan timur, dimana sumur terbuka atau kolam akan terletak di timur laut);

Vastu Shastra tidak hanya digunakan untuk merencanakan sebuah bangunan, tetapi juga untuk merencanakan desa hingga kota. Perencanan kota juga membutuhkan diagram VastuPurusha-Mandala. Diagram Vastu-Purusha-Mandala tersebut berupa kotak yang didalamnya terdapat kotak-kotak lain yang ukurannya lebih kecil. Kotak-kotak tersebut kemudian akan membentuk sebuah zona-zona yang dimulai dengan menyelaraskan jalan-jalan utama yang menyerupai bentuk salib kosmik. Dari penyelarasan jalan-jalan utama tersebut, kemudian dibagi ke dalam zona-zona yang dikembangkan menjadi sebuah diagram yang ditempati oleh kelas manusia yang berbeda. Diagram kelas manusia tersebut disusun berdasarkan tatanan sosial atau kasta yang diawali dengan alun-alun pusat yang disebut dengan Brahmasthana yang ditempati sebuah kuil atau istana, kemudian mengikuti zona Brahmana (Kaum terpelajar), zona Ksatriyas (pengelola/pengurus), zona Vaishyas (Pengusaha), hingga zona terluar adalah Shudras (rakyat jelata) yang membentuk diagram [8] sebagai berikut.

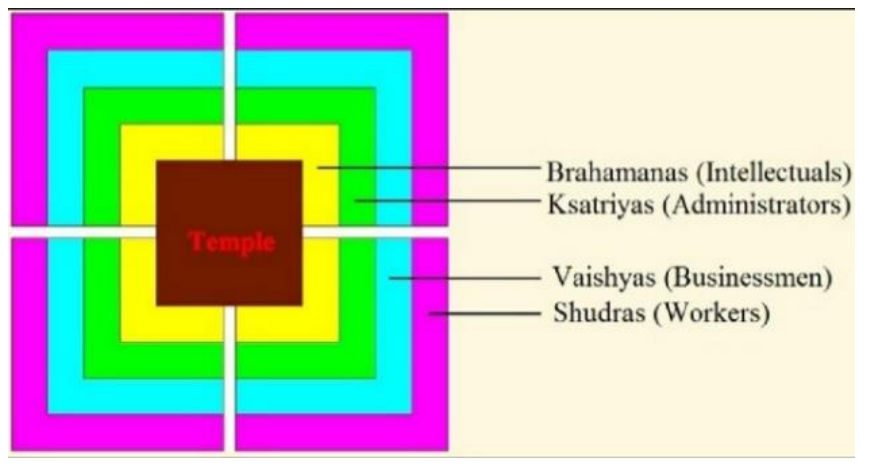

Gambar 1. Diagram Zona Kasta

Secara umum, perencanaan kota Vastu juga mengatur peletakan beberapa tempat khusus yaitu istana harus berada di pusat kota dengan arah hadap yang mengarah ke timur, kemudian bangunan bagi pendeta diletakkan pada timur laut, tempat perdagangan berada di tenggara, dan bangunan kuil berada di sisi utara istana dengan pohon-pohon besar yang mendominasi pusat kota atau disebut dengan pohon Bodhi yang digunakan sebagai tempat berkumpulnya masyarakat kota [8].

Kota Vastu terdiri dari delapan tipe yaitu sebagai berikut:

1. Dandaka, tipe kota yang berbentuk persegi atau persegi panjang dengan jalan-jalan lurus yang memiliki ukuran lebar bervariasi dan saling berpotongan membentuk tegak lurus di tengah serta terdapat empat gerbang yang berada di empat sisinya. Di ujung jalan tersebut, ada jalan yang melintang dengan satu baris rumah-rumah. 
2. Sarvatobhadra, tipe kota yang ditujukan untuk kota besar dengan bentuk dasarnya adalah persegi. Di tipe kota ini, kuil adalah bangunan yang mendominiasi dan harus dipenuhi dengan rumah-rumah dari berbabagi kelas.

3. Nandyavarta, tipe kota yang digunakan untuk pembangunan kota (bukan desa) dengan bentuk dasarnya adalah lingkaran atau persegi. Isi rumah atau bangunan di dalamnya juga memiliki batas tertentu yaitu 30004000 rumah. Jalan-jalannya diatur secara paralel ke jalan-jalan pusat yang berdampingan dengan kuil dewa yang memimpin di pusat kotanya.

4. Padmaka, tipe kota yang bentuknya menyerupai kelopak bunga teratai yang memancar keluar dari pusat serta dikeliling benteng di sekeliling kotanya.

5. Swastika, tipe kota yang bentuknya tidak harus persegi atau persegi panjang, dengan dua jalan utama yang saling berpotongan di pusat, dari selatan - utara dan barattimur. Kota ini juga dikelilingi benteng yang disertai parit dipenuhi air di bagian bawah benteng yang.

6. Prastara, tipe kota yang berbentuk persegi atau persegi panjang. Pada tipe kota ini, tiap kelas sosial akan dipisahkan (orang miskin, orang menengah, orang kaya, dan orang sangat kaya) dengan ukuran area permukimannya yang disesuaikan berdasarkan kapasitas tiap kelas untuk membeli atau membangun. Jalan utama kota ini harus memiliki ukuran yang lebih lebar dibanding jalan-jalan lainnya. Selain itu, tipe kota ini dapat dikelilingi benteng, namun juga bisa tidak dikelilingi benteng.

7. Karmuka, tipe kota yang berbentuk busur atau setengah lingkaran atau parabola. Tipe kota ini ditujukan untuk kota-kota yang terletak di tepi pantai atau tepi sungai. Jalan utamanya membentang dari utara - selatan atau timur-barat dan jalan-jalan lainnya membentang berpotongan membelah seluruh area menjadi blok-blok.

8. Chaturmuka, tipe kota yang berlaku untuk semua ukuran kota, mulai dari kota besar hingga desa kecil. Bentuk kotanya adalah persegi atau persegi panjang dengan empat wajah yang terbentuk dari bertemunya empat jalan utama yang ditata memanjang dari timurbarat, serta di bagian tengah kotanya akan terdapat kuil dewa ketua.

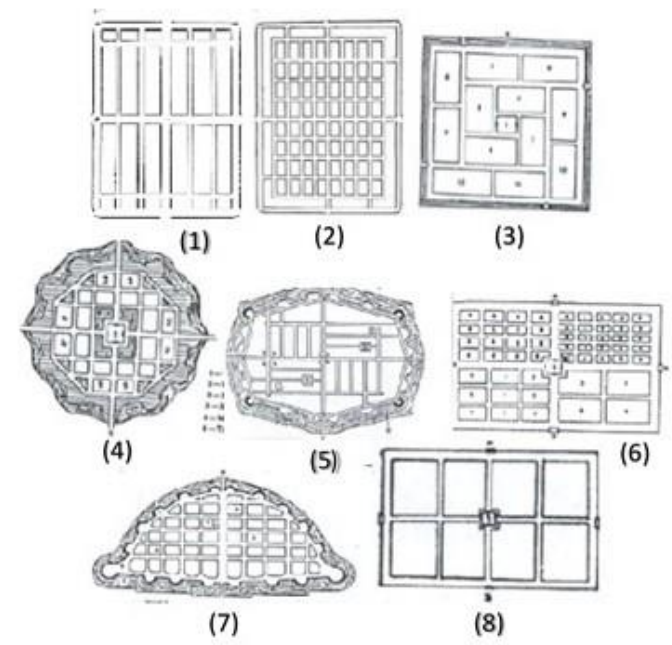

Gambar 2. Tipe Kota Vastu; (1) Dandaka; (2) Sarvatobhadra; (3)

Nandyavarta; (4) Padmaka; (5) Swastika; (6) Prastara; (7)Karmuka; (8) Chaturmuka

\section{METODE PENELITIAN}

Pendekatan yang digunakan di penelitian ini yaitu pendekatan kualitatif. Pendekatan kualitatif merupakan pendekatan yang mencirikan informasi yang saling terkait untuk menunjukkan adanya pola-pola atau teori yang akan menjelaskan fenomena sosial. Dalam hal ini, penelitian akan mendeskripsikan tentang fenomena dari pola ruang di Kerajaan Majapahit, Kecamatan Trowulan, untuk menunjukkan pola dari adanya adaptasi konsep Vastu Shastra.

\section{A. Variabel}

Variabel dalam penelitian ini adalah benda cagar budaya (BCB) Kerajaan Majapahit yang ada di Kecamatan Trowulan terkait gramatika Vastu, serta prinsip-prinsip Vastu Shastra (doktrin orientasi dan perencanaan lokasi) dan konsep dasar Vastu dalam penataan kota.

\section{B. Pengumpulan Data}

Penelitian ini mengumpulkan data melalui survei primer dan survei sekunder. Survei primer dilakukan dengan wawancara in depth interview (IDI) sebagai proses pendalaman informasi berdasarkan hasil pengumpulan data survei sekunder, yaitu dengan studi literatur.

\section{Tahap Penelitian}

Penelitian ini dilakukan dengan melalui empat tahap yaitu analisis studi benda cagar budaya Kerajaan Majapahit, klasifikasi struktur ruang berdasarkan Vastu Shastra, rekonstruksi ruang Kerajaan Majapahit, dan komparasi hasil rekonstruksi ruang dengan prinsip-prinsip Vastu Shastra.

\section{Analisis Data}

Analisis yang digunakan di dalam penelitian ini adalah content analysis untuk mengumpulkan keberadaan konsep terkait penataan ruang Kerajaan Majapahit yang kemudian dikomprasikan dengan konsep Vastu Shastra. 


\section{HASIL DAN PEMBAHASAN}

\section{A. Peninggalan Kerajaan Majapahit di Kecamatan Trowulan}

Peninggalan-peninggalan kerajaan Majapahit di Kecamatan Trowulan serta letak persebarannya dapat mendukung pembentukan tatanan ruang kerajaan Majapahit. Adapun peninggalan kerajaan Majapahit di Kecamatan Trowulan telah diteliti berdasarkan penemuan Wardenar pada tahun 1815 [9] serta berdasarkan data Dinas Pariwisata Kepemudaan dan Olahraga (Disparpora) Kabupaten Mojokerto sebagai berikut:

1. Candi Wringin Lawang, merupakan gapuran yang diduga sebagai gerbang masuk menuju ibu kota Majapahit. Candi ini ditemukan di sisi timur laut dari kolam Segaran yaitu berada di Desa Jatipasar.

2. Candi Brahu, merupakan candi yang diduga sebagai tempat penyimpanan abu keluarga kerajaan. Candi ini ditemukan di sisi barat laut Kecamatan Trowulan, yaitu di Desa Bejijong.

3. Candi Gentong, merupakan candi yang digunakan sebagai tempat upacara khusus memperingati Tribuana Wijaya, untuk meminta kesejahteraan. Candi ini ditemukan di sisi barat laut Kecamatan Trowulan yaitu di Desa Bejijong.

4. Candi Bajangratu, merupakan candi yang digunakan sebagai pintu untuk masuk ke bangunan suci, namun ada juga yang menduga sebagai gerbang selatan untuk menuju pusat kota Majapahit. Candi ini ditemukan di sisi tenggara Kecamatan Trowulan, yaitu di Desa Temon.

5. Kolam Segaran, merupakan kolam multiguna sebagai tempat pemandian, tempat menjamu tamu, dan tempat berkumpulnya prajurit sebelum dikirim untuk misi perang. Situs ini ditemukan di sisi utara dari alun-alun yaitu di Desa Trowulan.

6. Candi Tikus, merupaakan candi yang dianggap sebagai sumber air kehidupan dan juga sebagai pengatur debit air. Candi ini ditemukan di Desa Temon, dekat dengan Candi Bajangratu.

7. Candi Minak Jingga, merupakan candi yang dipercaya sebagai kuil yang dibangun dengan batu hitam. Candi ini ditemukan di sisi timur Kolam Segaran di Desa Trowulan.

8. Pendopo Agung, didirikan di atas umpak batu yang diyakini sebagai tempat pembacaan Sumpah Palapa dan .di sekitarnya juga ditemukan patok kayu yang diduga sebagai tempat mengikat gajah. Bangunan ini terletak di Desa Sentonorejo.

9. Candi Kedaton dan Sumur Upas, merupakan candi yang diduga sebagai kursi kerajaan raja untuk beraudiensi kepada pejabat senior. Candi dan sumur tersebut terletak di dekat tempat yang diduga sebagai Siti Inggil yang merujuk pada penentuan letak istana, yaitu di Desa Sentonorejo.

10. Situs Lantai Segi Enam, merupakan bekas permukiman masa Majapahit. Situs ini ditemukan di dekat letak Candi Kedaton yaitu di Desa Sentonorejo.

Penemuan peninggalan-peninggalan tersebut di Kecamatan Trowulan menunjukkan adanya tiga jenis ruang di kota Majapahit yaitu area kompleks istana, area pusat kota, dan Kecamatan Trowulan sebagai kota Majapahit itu sendiri.

\section{B. Tata Ruang Kerajaan Majapahit di Kecamatan Trowulan}

Tata ruang kerajaan Majapahit di Kecamatan Trowulan berdasarkan penemuan peninggalan-peninggalannya, dibagi menjadi tiga jenis area, yaitu area kompleks istana Kerajaan Majapahit, area pusat kota Majapahit, dan Kecamatan Trowulan sebagai kota Majapahit sebagai berikut:

1. Area Kompleks Istana

Area kompleks istana berkaitan dengan konsep hunian raja dan keluarga Kerajaan Majapahit. Kompleks istana kerajaan Majapahit termasuk ke dalam konsep hunian bangsawan yang berupa sebuah kompleks bangunan yang dikelilingi dinding dengan dua jenis halaman, yaitu halaman untuk bangunan-bangunan pendukung dan halaman untuk bangunan-bangunan tempat tinggal raja dan keluarganya [10].

Sttuterheim meneliti deskripsi Kitab Negarakertagama oleh Mpu Prapanca dan menemukan bahwa gerbang masuk kompleks istana berada di sisi utara, dalam hal ini menandakan bahwa istana Majapahit menghadap ke arah utara yang dipercaya secara khusus mengarah ke arah gunung suci, yaitu Gunung Penanggungan. Memasuki gerbang, ditemukan halaman yang terdapat berbagai jenis paviliun, dengan paviliun khusus adu ayam berada di tengah. Masuk ke area lebih dalam terdapat halaman yang dijaga oleh prajurit berbentuk segi empat dan dikelilingi dinding. Setelah halaman tersebut, pada area lebih dalam (arah selatan) terdapat halaman yang memilik dasar bangunan yang lebih tinggi yang diduga sebagai tempat raja duduk dengan dewan kerajaan dan para pejabat tinggi. Kemudian, area khusus kediaman raja Hayam Wuruk dan keluarganya berada di sisi tenggara kompleks istana [11]-[12]. Selain penemuan Sttuterheim berdasarkan deskripsi Kitab Negarakertagama, Vistarini, Pont, dan Wardenar juga melakukan penelitian langsung di lapangan dan menemukan beberapa penemuan. Vistarini dan Pont menemukan kolam dan sumur yang letaknya tersebar di sekitar area kompleks istana yaitu di sisi timur, barat laut, dan sisi tengah sedangkan Wardenar menemukan adanya keberadaan 26 paviliun yang berstruktur kayu dan bambu [12].

2. Area Pusat Kota

Sttuterheim berdasarkan Kitab Negarakertagama juga mendeskripsikan area pusat kota Majapahit. Di area pusat kota terdapat satu titik utama yaitu Catuspatha atau persimpangan suci yang terbentuk dari pertemuan empat jalan utama. Dari Catuspatha tersebut, digambarkan peletakan-peletakan tempat, seperti kompleks istana yang berada di sudur barat daya dari Catuspatha, alun-alun yang berada di sisi utara dari kompleks istana (sudut barat laut dari Catuspatha), kediaman pejabat-pejabat lainnya yang tersebar di sudut timur laut dan sudut tenggara, serta bangunan pendeta dan halaman kuil yang juga berada di sisi sudut timur laut dari Catuspatha [11]-[12]. Dari deskripsi Sttuterheim tersebut, Hermanislamet menggambarkan adanya konsep Perempatan Agung tentang pusat kota Majapahit yang terdiri dari tempat peribadatan, open space, dan kraton [13]. 


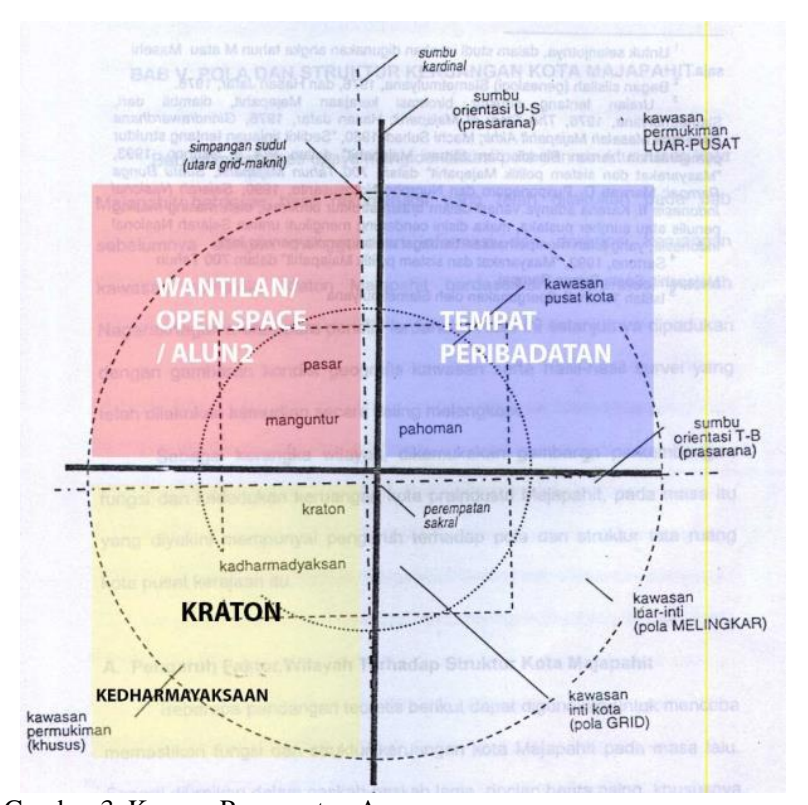

Gambar 3. Konsep Perempatan Agung

3. Kecamatan Trowulan sebagai Kota Majapahit

Kecamatan Trowulan merupakan sebuah daerah perkotaan pada masa Majapahit. Hal tersebut didasarkan atas penelitian Pont yang menggambarkan bentuk pengunaan lahannya yang mencirikan kawasan perkotaan yang tidak ditemukan penggunaan lahan untuk kegiatan agraria di dalamnya [14].

Hermanislamset melakukan penelitian berdasarkan para ahli sebelumnya dan menemukan bahwa kota Majapahit terdiri dari beberapa unsur [13] yaitu sebagai berikut.

Tabel 1.

Unsur-unsur Kota Majapahit

\begin{tabular}{|c|c|c|c|}
\hline No. & $\begin{array}{l}\text { Unsur Kota } \\
\text { Majapahit }\end{array}$ & Letak & Fungsi \\
\hline 1. & Dinding & $\begin{array}{l}\text { Hanya } \\
\text { mengelilingi } \\
\text { kompleks } \\
\text { istana/kraton }\end{array}$ & $\begin{array}{l}\text { Sebagai sifat terbuka } \\
\text { untuk warganya dan } \\
\text { sebagai batas hal milik } \\
\text { atau privasi bagi petinggi } \\
\text { kerajaan }\end{array}$ \\
\hline 2. & Gapura & $\begin{array}{l}\text { Empat sisi } \\
\text { kota } \\
\text { Majapahit } \\
\text { (Trowulan) }\end{array}$ & $\begin{array}{l}\text { Sebagai gerbang resmi } \\
\text { untuk keluar masuk kota }\end{array}$ \\
\hline 3. & $\begin{array}{l}\text { Lapangan umum } \\
\text { kota }\end{array}$ & $\begin{array}{l}\text { Pusat kota } \\
\text { Majapahit }\end{array}$ & $\begin{array}{l}\text { Mendukung terbentuknya } \\
\text { pola kota Majapahit } \\
\text { (adanya jaringan } \\
\text { prasarana yang } \\
\text { berpotongan tegak lurus } \\
\text { di pusat kota) }\end{array}$ \\
\hline 4. & $\begin{array}{l}\text { Balai pertemuan } \\
\text { umum }\end{array}$ & $\begin{array}{l}\text { Sebelah utara } \\
\text { luar Kraton }\end{array}$ & $\begin{array}{l}\text { Tempat bertemunya para } \\
\text { petinggi kerajaan }\end{array}$ \\
\hline 5. & Pasar & - & - \\
\hline 6. & $\begin{array}{l}\text { Bangunan suci } \\
\text { dan tempat sesaji }\end{array}$ & $\begin{array}{l}\text { Timur laut } \\
\text { Kraton }\end{array}$ & $\begin{array}{l}\text { Sebagai tempat } \\
\text { peribadahan dan tempat } \\
\text { sesaji agama Hindu } \\
\text { (Siwa) dan Budha }\end{array}$ \\
\hline
\end{tabular}

\begin{tabular}{|c|c|c|c|}
\hline 7. & Kraton/istana & $\begin{array}{l}\text { Area barat } \\
\text { dan barat } \\
\text { daya }\end{array}$ & $\begin{array}{l}\text { Sebagai tempat tinggal } \\
\text { raja dan keluarganya } \\
\text { dengan tiga lapis halaman } \\
\text { dan tiga gerbang (satu } \\
\text { gerbang utama) }\end{array}$ \\
\hline 8. & $\begin{array}{l}\text { Kepatihan/tempat } \\
\text { tinggal raja }\end{array}$ & $\begin{array}{l}\text { Sebelah utara } \\
\text { dan timur } \\
\text { laut Kraton }\end{array}$ & $\begin{array}{l}\text { Tempat tinggal perdana } \\
\text { meneteri Majapahit (patih } \\
\text { Gajah Mada) dan tempat } \\
\text { tinggal walikota-walikota } \\
\text { kerajaan Majapahit }\end{array}$ \\
\hline 9. & $\begin{array}{l}\text { Tempat tinggal } \\
\text { rohaniwan }\end{array}$ & $\begin{array}{l}\text { Di dalam } \\
\text { Kraton dan } \\
\text { selatan luar } \\
\text { Kraton }\end{array}$ & $\begin{array}{l}\text { Dikenal sebagai } \\
\text { "Kedharmmayaksaan" } \\
\text { untuk tempat tinggal } \\
\text { rohaniwan agama Hindu } \\
\text { (Siwa) dan Budha }\end{array}$ \\
\hline
\end{tabular}

Selain unsur-unsur tersebut, sebuah kota tidak dapat dipisahkan dari adanya pola di dalamnya. Pola kota Majapahit berpola grid di bagian pusat kotanya dan berpola melingkar. Pola kota tersebut dipengaruhi adanya manifestasi tatanan sosial di dalamnya yang terbentuk dari kawasan formal menjadi kawasan nonformal. Kawasan formal dan nonformal tersebut didasarkan kepada manifestasi sistem kerajaan, yaitu kawasan formal untuk kawasan khusus kegiatan pemerintahan hingga kawasan nonformal yang tidak berkaitan secara langsung dengan kegiatan pemerintahan. Pada area pusat kota Majapahit sendiri terdiri dari kawasan yang bercirikan kegiatan pemerintahan, kegiata n spiritual (keagamaan), dan kegiatan fungsional untuk menambah pemasukan kerajaan [15]. Adanya pembagian tata ruang, jaringan jalan yang berbentuk grid serta adanya kepercayaan akan poros dari dataran tinggi (gunung suci) ke dataran rendah (laut) akan membentuk aliran udara yang mengalir bebas sehingga dapat mengurangi suhu dan kelembapan pada kota [16].

\section{Rekonstruksi Kerajaan Majaphit di Kecamatan Trowulan}

Rekonstruksi Kerajaan Majapahit di Kecamatan Trowulan didasarkan kepada deskripsi dan visualisasi penelitian beberapa ahli sebelumnya mengenai tata ruang Kerajaan Majapahit. Penulis membuat rekonstruksi yang didasarkan atas penemuan-penemuan peninggalan Majapahit yang ada di Kecamatan Trowulan. Hasil rekonstruksi oleh penulis menunjukkan bahwa Kecamatan Trowulan merupakan area pusat kota. Hal tersebut terlihat dari persebaran benda peninggalannya yang berada di pola jaringan yang diteliti oleh Bakosurtanal, yang membentuk pola grid. Namun, ada beberapa peninggalan di Kecamatan Trowulan yang tidak termasuk ke dalam pola grid tersebut, yaitu Candi Wringin Lawang, Candi Gentong, dan Candi Brahu. Dari hal ini, dapat disimpulkan bahwa ketiga benda peninggalan tersebut merupakan bangunan-bangunan yang berada di luar pusat kota. Candi Wringin Lawang yang diduga merupakan gerbang utara untuk menuju pusat kota Majapahit tidak terletak tepat di arah utara dan tidak terletak sejalan dengan jalan utama. Selain itu, Candi Bajangratu yang juga diduga sebagai gerbang selatan untuk menuju ke pusat kota justru terletak di sebelah timur. Hermanislamet di deskripsi sebelumnya menyebutkan terdapat empat gerbang di keempat sisi kotanya. Namun, keberadaan gerbang tersebut tidak ditemukan di Kecamatan Trowulan. Namun, 
konsep perempatan agung yang dikemukakan Hermanislamet dapat dikatakan tepat. Hal tersebut terlihat dari letak penemuan situs lantai segi enam yang diduga merupakan bagian sebuah permukiman didukung dengan keberadaan sumur upas dan candi kedaton yang merujuk kepada letak istana kerajaan Majapahit yaitu berada di sisi barat daya dari sebuah perempatan. Penemuan Wardeenar terhadap sebuah tanah gersang tepat di sebelah utara dari yang merujuk pada alun-alun di depan tempat tinggal raja, serta letak Minak Jingga yang berada di sisi timur laut dari perempatan, dimana Minak Jingga merujuk pada keberadaan sebuah kuil. Dari penemuan-penemuan dan peletakan benda peninggalan tersebut, penulis menyimpulkan bahwa jaringan tegak lurus yang dikelilingi alun-alun dan istana tersebut adalah Catuspatha atau perempatan agung.

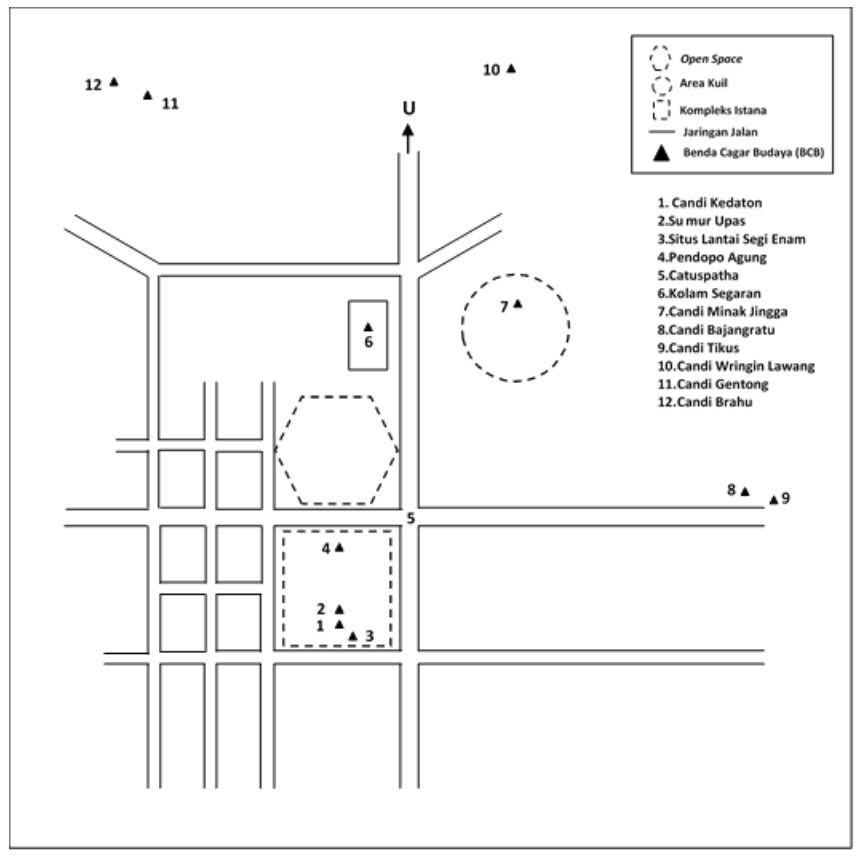

Gambar 4. Hasil Rekonstruksi Kerajaan Majapahit di Kecamatan Trowulan

\section{Komparasi Kerajaan Majapahit dengan Konsep Vastu Shastra}

Komparasi akan terbagi menjadi tiga bagian sesuai dengan pembagian pada tata ruang kerajaan Majapahit yaitu terdiri dari: komparasi kompleks istana Majapahit dengan prinsip Vastu Shastra (doktrin orientasi dan kriteria perencanaan lokasi); komparasi pusat kota dan Kecamatan Trowulan sebagai kota Majapahit dengan konsep dasar Vastu dalam Penataan Kota; serta hasil rekonstruksi Kerajaan Majapahit di Kecamatan Trowulan dengan delapan tipe kota Vastu sebagai berikut.

1. Komparasi Kompleks Istana Majapahit dengan Prinsip Vastu Shastra

Kompleks istana Majapahit berdasarkan deskripsi sebelumnya dikomparasikan prinsip Vastu Shastra yang merujuk pada perencanaan sebuah bangunan hunian yang terdiri dari doktrin orientasi dan perencanaan lokasi (orientation, living area, floor plans, thermal mass, dan water harvesting) sebagai berikut.
Tabel 2.

Hasil Komparasi Kompleks Istana Majapahit dengan Prinsip Vastu Shastra

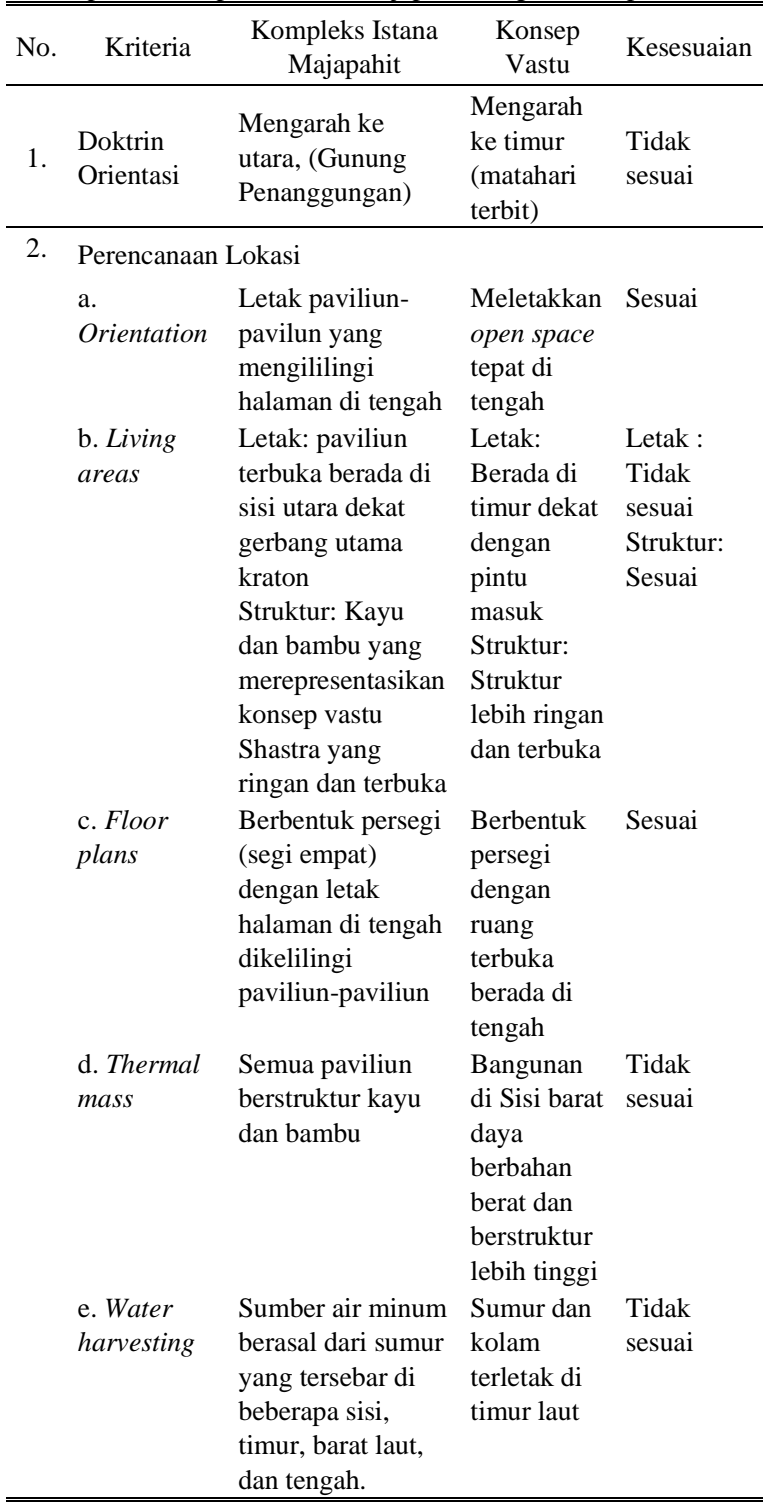

Berdasarkan komparasi tersebut, ditemukan bahwa Penentuan arah hadap pada Kerajaan Majapahit dan Konsep Vastu tidak menemukan kesesuaian. Istana Majapahit menghadap ke utara dengan makna mengikuti letak gunung suci, dan konsep Vastu mengarah ke timur untuk mengikuti arah datangnya matahari terbit sebagai kemurnian. Perencanaan lokasi istana Majapahit dengan konsep Vastu menunjukkan kesesuaian yang mencapai 50\% pada kriteria: Orientation dengan meletakkan ruang terbuka di tengah; Living Areas dengan struktur bangunan untuk area tamu yang berstruktur ringan dan terbuka; serta Floor Plans dengan bentuk bangunan adalah persegi dan letak ruang terbuka yang berada di tengah.

2. Komparasi antara Pusat Kota Majapahit dan Kecamatan Trowulan sebagai kota Majapahit dengan Konsep Dasar Vastu dalam Penataan Kota

Hasil rekonstruksi kota Majapahit di Kecamatan Trowulan menunjukkan bahwa Kecamatan Trowulan merupakan kawasan pusat kota Majapahit, sehingga hasil rekonstruksi 
tersebut akan dikomparasikan dengan konsep dasar Vastu dalam penataan ruang berdasarkan kriteria pusat kotanya, susunan kota, dan peletakan tempatnya secara khusus sebagai berikut.

Tabel 3.

Hasil Komparasi Kecamatan Trowulan sebagai kota Majapahit dengan Konsep Dasar Vastu dalam Penataan Kota

\begin{tabular}{|c|c|c|c|c|}
\hline No. & Kriteria & $\begin{array}{c}\text { Kecamatan } \\
\text { Trowulan } \\
\text { sebagai Kota } \\
\text { Majapahit } \\
\end{array}$ & $\begin{array}{l}\text { Konsep Dasar } \\
\text { Vastu }\end{array}$ & Kesesuaian \\
\hline 1. & Pusat Kota & $\begin{array}{l}\text { Kecamatan } \\
\text { Trowulan } \\
\text { sebagai pusat } \\
\text { kota ditempati } \\
\text { istana, alun- } \\
\text { alun, dan kuil }\end{array}$ & $\begin{array}{l}\text { Pusat kota } \\
\text { ditempati alun- } \\
\text { alun pusat, kuil, } \\
\text { atau istana }\end{array}$ & Sesuai \\
\hline 2. & Susunan Kota & $\begin{array}{l}\text { Kecamatan } \\
\text { Trowulan } \\
\text { merupakan } \\
\text { kawasan formal } \\
\text { untuk kegiatan } \\
\text { pemerintahan, } \\
\text { spiritualitas, dan } \\
\text { fungsional } \\
\end{array}$ & $\begin{array}{l}\text { Kota disusun } \\
\text { berdasarkan } \\
\text { tatanan sosial } \\
\text { menurut kasta }\end{array}$ & Tidak sesuai \\
\hline
\end{tabular}

3. Peletakan Tempat

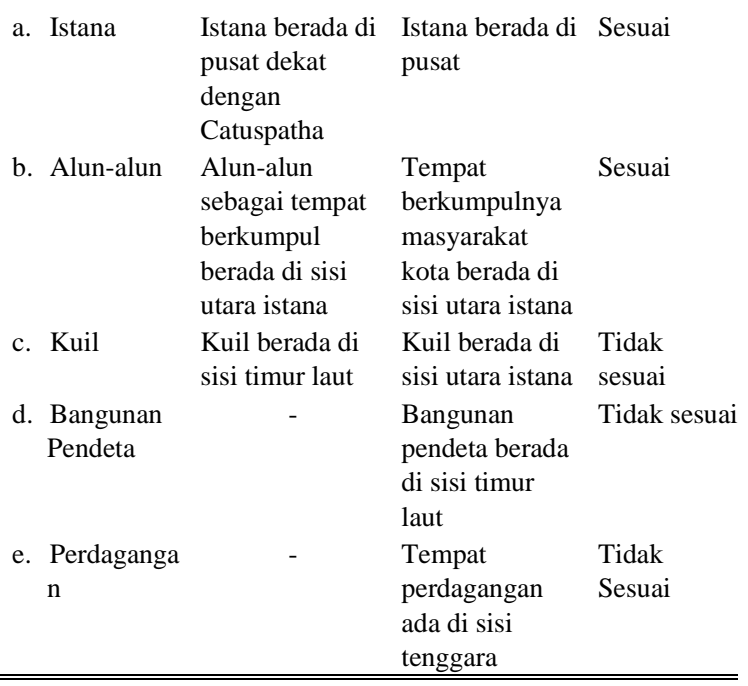

Berdasarkan komparasi tersebut, didapatkan bahwa Konsep pusat kota dan kota Majapahit di Kecamatan Trowulan dengan konsep dasar perencanaan kota Vastu menunjukkan kesesuaian dalam kriteria Pusat Kota, yaitu Kecamatan Trowulan sebagai pusat kota ditempati alun-alun, istana, dan kuil; serta Peletakan tempat, yaitu letak istana yang berada di pusat dan letak alun-alun sebagai tempat berkumpul berada di sisi utara dari istana

3. Komparasi antara Hasil Rekonstruksi Kerajaan Majapahit di Kecamatan Trowulan dengan Tipe Kota Vastu

Komparasi kota Majapahit di Kecamatan Trowulan menunjukkan adanya kesesuaian, maka hasil rekonstruksi dari kota Majapahit Trowulan dikomparasikan kembali dengan delapan tipe kota Vastu melalui overlay gambar hasil rekonstruksi kerajaan Majaphit tersebut dengan gambar desain tiap tipe kota Vastu serta beberapa kriteria khusus di dalamnya sebagai berikut.
a.Dandaka

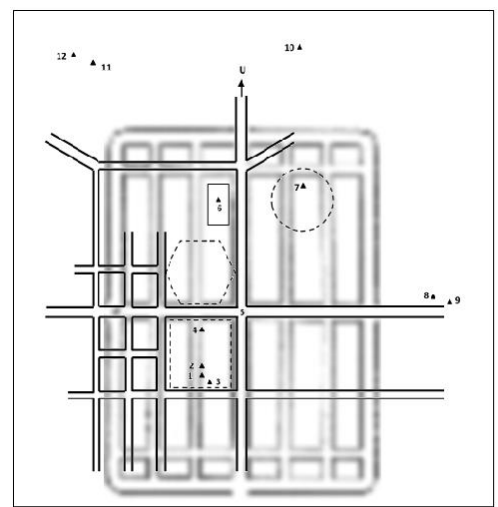

Gambar 5. Overlay Rekonstruksi Kota Majapahit dengan Tipe Kota Dandaka

b.Sarvatobhadra

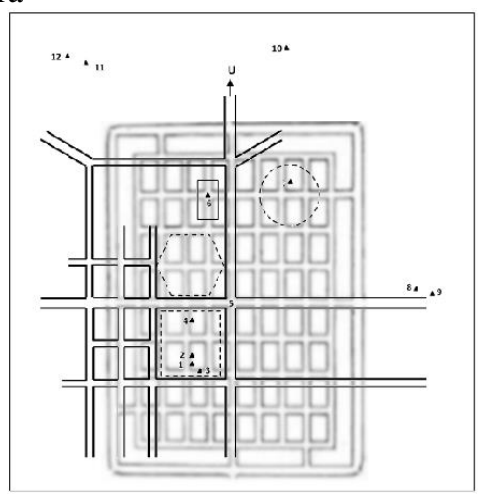

Gambar 6. Overlay Rekonstruksi Kota Majapahit dengan Tipe Kota Sarvatobhadra

c. Nandyavarta

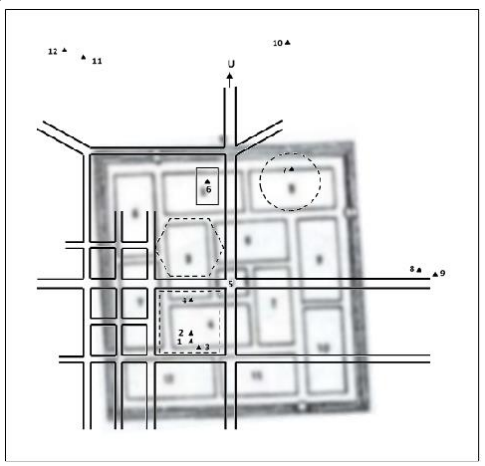

Gambar 7. Overlay Rekonstruksi Kota Majapahit dengan Tipe Kota Nandyavarta

d.Padmaka

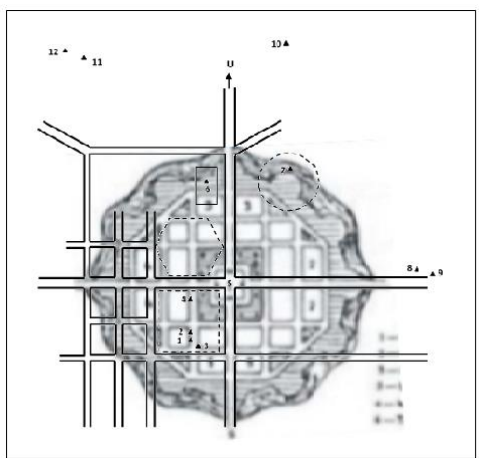

Gambar 8. Overlay Rekonstruksi Kota Majapahit dengan Tipe Kota Padmaka 
e.Swastika

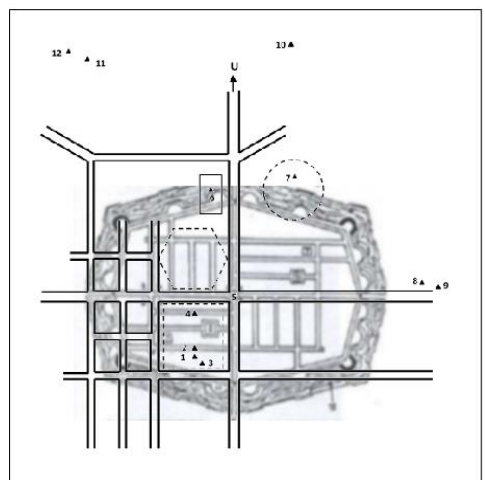

Gambar 9. Overlay Rekonstruksi Kota Majapahit dengan Tipe Kota Swastika

\section{f. Prastara}

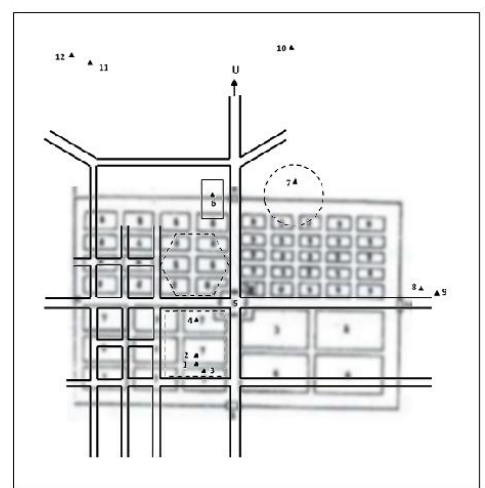

Gambar 10. Overlay Rekonstruksi Kota Majapahit dengan Tipe Kota Prastara

g.Karmuka

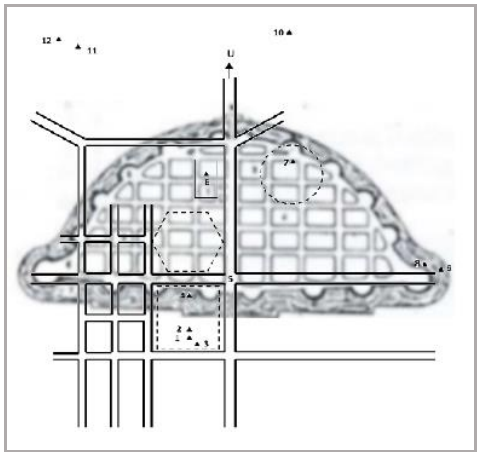

Gambar 11. Overlay Rekonstruksi Kota Majapahit dengan Tipe Kota Karmuka

h.Chaturmuka

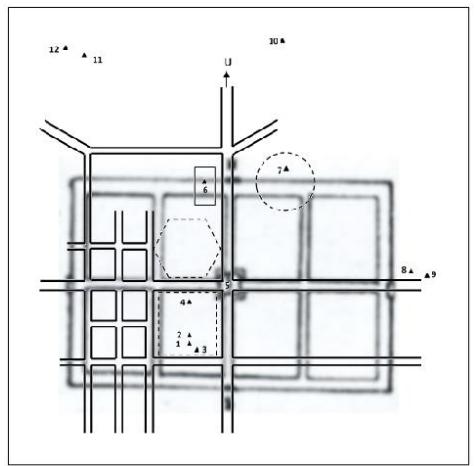

Gambar 12. Overlay Rekonstruksi Kota Majapahit dengan Tipe Kota Chaturmuka
Overlay yang mengkomparasikan hasil rekonstruksi kota Majapahti di Kecamatan Trowulan dengan delapan tipe kota Vastu menunjukkan hasil sebagai berikut.

Tabel 4.

Hasil Komparasi Rekonstruksi Kerajaan Majapahit di Kecamatan Trowula dengan Tipe Kota Vastu

\begin{tabular}{|c|c|c|c|c|c|c|c|c|}
\hline Kriteria & \begin{tabular}{l}
$\searrow$ \\
$\vdots$ \\
$\vdots$ \\
\multirow{\Sigma}{*}{}
\end{tabular} & 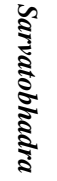 & 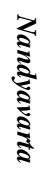 & 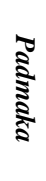 & 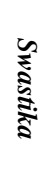 & 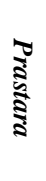 & 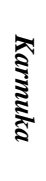 & 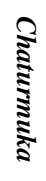 \\
\hline Pusat Kota & $\mathrm{v}$ & $\mathrm{v}$ & $\mathrm{x}$ & $\mathrm{x}$ & $\mathrm{x}$ & $\mathrm{x}$ & $\mathrm{x}$ & $\mathrm{x}$ \\
\hline $\begin{array}{l}\text { Jalan } \\
\text { Utama }\end{array}$ & $\mathrm{v}$ & $\mathrm{v}$ & $\mathrm{x}$ & $\mathrm{v}$ & $\mathrm{v}$ & $\mathrm{v}$ & $\mathrm{x}$ & $\mathrm{v}$ \\
\hline Dinding & $\mathrm{v}$ & $\mathrm{v}$ & $\mathrm{x}$ & $\mathrm{x}$ & $\mathrm{x}$ & $\mathrm{v}$ & $\mathrm{x}$ & $\mathrm{v}$ \\
\hline $\begin{array}{l}\text { Penataan } \\
\text { Bangunan }\end{array}$ & $\mathrm{x}$ & $\mathrm{x}$ & $\mathrm{x}$ & $\mathrm{x}$ & $\mathrm{x}$ & $\mathrm{v}$ & $\mathrm{x}$ & $\mathrm{v}$ \\
\hline $\begin{array}{l}\text { Kriteria } \\
\text { khusus }\end{array}$ & $\mathrm{x}$ & $\mathrm{x}$ & $\mathrm{x}$ & $\mathrm{x}$ & $\mathrm{x}$ & $\mathrm{x}$ & $\mathrm{x}$ & $\mathrm{x}$ \\
\hline Total & 3 & 3 & 0 & 1 & 1 & 3 & 0 & 3 \\
\hline
\end{tabular}

Tipe kota yang memiliki kriteria terbanyak yang sesuai dengan kota Majapahit di Kecamatan Trowulan ada 4 (empat), yaitu Dandaka, Sarvatobhadra, Prastara, dan Chaturmuka dengan jumlah kriteria yang sama yaitu 3 dari 5 kriteria atau $60 \%$ dari keseluruhan kriteria. Dandaka dan Sarvatobhadra memiliki kesamaan kriteria pusat kota, jalan utama, dan dinding yang mengelilingi kota sedangkan Prastara dan Chaturmuka memiliki kesamaan kriteria jalan utama, dinding, dan penataan bangunannya.

\section{KESIMPULAN DAN SARAN}

Penelitian ini menunjukkan bahwa Kerajaan Majapahit di Kecamatan Trowulan mengadaptasi konsep Vastu mulai dari konsep permukiman hingga dalam penataan kotanya. Meskipun begitu, kesesuaian konsep Vastu Shastra tidak seluruhnya relevan dengan tatanan ruang Kerajaan Majapahit melainkan hanya di bagian-bagian tertentu. Hasil penelitian ini dapat menjadi konsep penelitian perencanaan modern di masa sekarang dan masa mendatang untuk menuju perencanaan yang mengarah ke pembangunan berkelanjutan.

\section{DAFTAR PUSTAKA}

[1] Harrison, R. (2010). What is heritage. Understanding the politics of heritage.

[2] Nurjanah, S. (2013). Kosmologi dan sains dalam islam. Akdemika: Jurnal Pemikirian Islam.

[3] .Arinto, F. E. (2017). Gramatika Arsitektur Hunian Masyarakat Perdesaan Jawa di Desa Tirtosari. Disertasi, Universitas Katolik Parahyangan, Program Doktor Arsitektur, Bandung.

[4] Patra, R. (2008). Vastu Shastra: Towards Sustainable Development. doi: $10.1002 / \mathrm{sd} .388$

[5] Venugopal, J. (2012). Vastu Purusha Mandala-A Human Ecological Framework For Designing Living Environments. International Conference on Advances in Architecture and Civil engineering. Queensland: Queensland University of Technology.

[6] Ramsedt, M. (2005). Hinduism in Modern Indonesia. Routledge. 
[7] R. Siti Rukayah, T. R. (2013). The Sustainability Concept of Alun-Alun as a Model of Urban Design in the Future. Procedia-Social and Behavioral Sciences, 626-637

[8] Prajitha (2017). Basic Concept of Vastu for Town Planning.

[9] Gomperts, A., Haag, A., \& Carey, P. (2012). Mapping Majapahit: Wardenaar's archaeological survey at Trowulan in 1815. Indonesia, (93), 177-196.

[10] Munandar, A. A. (2011). Catuspatha: Arkeologi Majapahit. Wedatama Widya Sastra.

[11] Gomperts, A., Haag, A., \& Carey, P. (2008). Stutterheim's enigma: The mystery of his mapping of the Majapahit kraton at Trowulan in 1941. Bijdragen tot de taal-, land-en volkenkunde/Journal of the Humanities and Social Sciences of Southeast Asia, 164(4), 411-430.

[12] .Gomperts, A., Haag, A., Carey, P., \& Umbaran, D. (2014). Archaeological Identification of the Majapahit Royal Palace: Prapañca's 1365 Description Projected onto Satellite Imagery. The Journal of the Siam Society, 102, 67-118.

[13] Winarno, A. B., \& Saliya, Y. (2018). Presistensi Konsep Penataan Kota Praindustri Majapahit terhadap Penataan Kawasan Modern Studi Kasus pada Kampus UI, UB dan ITB. Jurnal RISA, 152-164.

[14] Adrisijanti, I. (2014). Majapahit: Batas Kota dan Jejak Kejayaan di Luar Kota. Yogyakarta: Kepel Press.

[15] Tjahja Tribinuka, dkk (2019). Analisis Ibukota Majapahit dari Segi Urban dan Permukiman. Surabaya: Abiyasa Nusantara

[16] Winarto, Y., Santosa, H. R., \& Ekasiwi, S. N. (2015). The Climate Concious Concept of Majapahit Settlement in Trowulan, East Java. $318-329$ 